\title{
THE SPILLOVER EFFECTS OF FDI ON LABOR PRODUCTIVITY OF FIRMS: \\ EVIDENCE FROM THE FIVE PRIORITY MANUFACTURING INDUSTRIES IN INDONESIA ${ }^{1}$
}

\author{
Martin Juda ${ }^{1}$, Toshihiro Kudo ${ }^{2}$ \\ Master of Economic Planning and Development Policy Program, Faculty of Economics and Business, \\ Universitas Indonesia, Depok Indonesia, martin.juda@gmail.com; \\ ${ }^{2}$ Economics, Planning, and Public Policy Program, National Graduate Institute for Policy Studies, Tokyo Japan, \\ toshihiro.kudo.japan@gmail.com
}

\begin{abstract}
This study aims to investigate the effects of FDI spillover on labor productivity of the firms in the five priority manufacturing sector industries in Indonesia, namely food and beverages, textiles, wearing apparel and footwear, chemicals and pharmaceuticals, electronics, and automotive and transport equipment industries. Using firmlevel data from 2000 to 2015, we find positive effects in the horizontal spillover, which measure the presence of foreign firms on the labor productivity of local firms in the same industry. However, the effects of FDI on the labor productivity of domestic in backward spillovers shows negative results, which means foreign buyers, fail to give benefits to domestic suppliers. Moreover, the relationship between foreign suppliers and domestic buyers in the forward spillovers also show negative effects. These findings are also in line when the analyses are disaggregated into each industry, except for the electronics industry. Based on the different results of the three spillovers, our findings suggest that the FDI spillover has not provided comprehensive benefits for local firms.
\end{abstract}

Keywords: Foreign direct investment, spillover effects, productivity, manufacturing, Indonesia

JEL Classification: F21, J24, L60

\begin{abstract}
Abstrak
Studi ini bertujuan untuk menginvestigasi efek spillover dari FDI pada produktivitas tenaga kerja perusahaan di lima prioritas industry di Indonesia, yaitu makanan dan minuman, tekstil, pakaian jadi dan alas kaki, kimia dan farmasi, elektronik, dan otomotif dan peralatan transportasi. Menggunakan data tingkat perusahaan dari tahun 2000 sampai dengan 2015, kami menemukan pengaruh positif dari efek horizontal spillover, yang mengukur keberadaan perusahaan asing terhadap produktivitas tenaga kerja perusahaan lokal di industri yang sama. Namun, efek FDI pada produktivitas tenaga kerja dalam backward spillovers menunjukkan hasil negatif, yang berarti perusahaan asing gagal memberikan manfaat kepada pemasok domestik. Selain itu, hubungan antara pemasok asing dan pembeli domestik dalam forward spillovers juga menunjukkan efek yang negatif. Temuan ini juga sejalan ketika analisis dipisahkan ke dalam setiap industri, kecuali untuk industri elektronik. Hasil yang berbeda dari tiga jenis keterkaitan spillovers menunjukkan bahwa FDI belum memberikan manfaat yang komprehensif untuk perusahaan lokal.
\end{abstract}

Kata kunci: Foreign direct investment, efek spillover, productivitas, manufaktur, Indonesia

Klasifikasi JEL: F21, J24, L60

\footnotetext{
${ }^{1}$ This study is part of author's master thesis at National Graduate Institute for Policy Studies (GRIPS) Japan and Universitas Indonesia
} 


\section{INTRODUCTION}

Most countries have seen inward foreign direct investment (FDI) as the driver of economic development. The reason is that FDI might give benefits to a country such as employment creation, business competitiveness, and productivity gains (OECD, 2002; Xaypanya et al., 2015). FDI is preferable to other types of investment because it is intended for the long term to avoid a sudden reversal of capital outflow when the economic shocks appear (Athukorala, 2003; Busse \& Hefeker, 2007).

Indonesia, being one of the emerging economies in the world, has good FDI prospects. According to the World Investment Report 2017, Indonesia is ranked number 4 on Multi National Enterprises (MNEs) top prospective host economies for the period of 2017-2019, behind the US, China, and India (UNCTAD, 2017). This situation is reflected in the data from the Central Bank of Indonesia (2018), which recorded an increasing trend of FDI inflow in Indonesia, from US $\$ 5,858$ million in 2004 to US $\$ 21,266$ million in 2017.

However, the growth of manufacturing industries in Indonesia has stagnated in the recent years. According to the data from Statistics Indonesia (2019), the average growth rate of manufacturing industries was $4.62 \%$ from 2001 until 2017. Compared to the services industries, which had a growth rate of $6.76 \%$ in the same period, the growth of the manufacturing industry is still considered low. Furthermore, the contribution of manufacturing industries to the total national output continued to decline gradually, going from $27.7 \%$ in 2000 to $25 \%$ in 2017 . Hence, the Ministry of Industry has prioritized five industries in the manufacturing sector based on its contribution to the economy. These industries were selected because they contribute up to $60 \%$ of the GDP in the manufacturing sector industries, $65 \%$ of the manufacturing exports, and $60 \%$ of the manufacturing labor.

Considering the investment prospects of Indonesia, it is expected that foreign investment in the five priority industries could be the driver of economic development. Furthermore, FDI could bring knowledge through the use of advanced technology that improves the economies of scale in the production process, which are beneficial in creating cheaper and better outputs (Moran, Graham, \& Blomstrom 2005). In addition to the use of technology, FDI also brings intangible assets that can enhance human capital productivity such as managerial skills, marketing proficiency, research and development activities, and adequate training resources (X. Liu et al., 2001; Negara \& Adam, 2012).

Moreover, the effect of FDI is not limited to direct impact on firms that have foreign ownership. The diffusion of knowledge and technology transfer from the FDI firms also affects local firms, which can raise their productivity (Crespo \& Fontoura, 2007; X. Liu et al., 2001). The impacts, which can be referred to as spillover effects, can take place in the same industry as horizontal spillovers, between foreign firms and domestic suppliers as backward spillovers, and between foreign firms and domestic buyers as forward spillovers (Crespo \& Fontoura, 2007).

Nevertheless, the evidence of the impacts of FDI spillovers has drawn different conclusions. Early empirical studies argue that horizontal spillovers could be insignificant or negative (Aitken \& Harrison, 1999; Djankov \& Hoekman, 2000; Konings, 2001). Recently, empirical studies in FDI spillovers had been developed in measuring vertical spillovers, which found to give more positive impacts than horizontal spillovers (Girma et al., 2016; Javorcik, 2004; Z. Liu, 2008). Surprisingly, in the case of Indonesian manufacturing industries, most empirical studies examined the negative influences of FDI spillovers through backward spillovers, while the positive impacts occurred in horizontal dan forward spillovers (Amani, 2017; Negara \& Adam, 2012; Sari et al., 2016). In contrast, another study in Indonesia conducted by Blalock and Gertler (2008) found no evidence about the impacts of horizontal spillovers, while the effects of vertical spillovers were significant and positive. Several factors might be the reasons in explaining this ambiguity: the different measures of productivity function and the variables of spillovers (Barbosa \& Eiriz, 2009; Barrios et al., 2011; Gorodnichenko et al., 2014), the methodology used in the estimations (Gorg \& Strobl, 2001), and the host countries' characteristics including the absorptive 
capacity of local firms (Blalock \& Simon, 2009; Gorodnichenko et al., 2014; Negara \& Adam, 2012).

The mixed results of the previous studies will be clarified in this study by answering the question: how do the three channels of the FDI spillovers affect the labor's productivity of local firms in the five priority industries in the manufacturing sector of Indonesia? In order to answer this question, this study contributes to existing literatures in three different ways. First, this study used broader time variations of input-output (I-O) tables than any other studies in Indonesia. By using three-time variations of I-O tables, it will give more relevant data in capturing industrial patterns in Indonesia, including the influence of new investment (Driffield \& Jindra, 2012). Second, this study analyzed the data in disaggregated level, which hardly found in Indonesia. The use of disaggregated level of data is preferable in capturing productivity because of the differences in the sources of productivity in each industry (Suyanto et al., 2012). Third, this study used labor productivity as the indicator of productivity function. According to Mahmood (2008), this indicator can capture technical efficiency due to its linkages between outputs and inputs with a given technology. Besides, as part of the multifactor productivity analysis, the use of labor productivity can reduce the limitation in productivity calculations due to the consequent ease of estimation, along with the clear identification.

This study found that the backward and forward linkages had negative effects, while the horizontal linkages positively contributed to the productivity of the firms in Indonesia. The analysis was based on the data from the Annual Survey of Medium and Large Manufacturing Industries in Indonesia between the years 2000 and 2015. To measure the backward and forward linkages, the I-O tables were used with the three-time variations - 2000, 2005, and 2010. Furthermore, the analysis of industry characteristics will be devoted to the five priority industries. These industries are (1) food and beverages, (2) textiles, wearing apparel and footwear, (3) chemicals and pharmaceuticals, (4) electronics, and (5) automotive and transport equipment ${ }^{2}$. The rest of this article is structured as follows: Section 2 presents the literature review of the effects of the FDI spillovers on labor productivity. Section 3 describes the data and the model that can influence labor productivity. Section 4 discusses empirical results of this study. Finally, section 5 provides conclusion and policy recommendations.

\section{LITERATURE REVIEW}

As stated in the previous section, FDI can bring benefits to the economic development of the host country through knowledge transfers, which can improve the productivity of the host country's firms. There are three arguments concerning how knowledge transfer can take place from foreign firms to local firms. First, local firms can learn and adapt to production activities, managerial skills, or technological processes introduced by FDI (Crespo \& Fontoura, 2007). Second, local firms can recruit former workers from foreign firms to utilize their skills and experience (Glass \& Saggi, 2002). Third, the entrance of FDI can increase the competitiveness of the market and stimulate local firms to innovate and be more productive for their survival (Chung, 2001).

Earlier empirical studies that attempted to investigate FDI spillovers had not provided the positive evidence that foreign presence could provide benefits to local firms (Aitken \& Harrison, 1999; Djankov \& Hoekman, 2000; Konings, 2001). Javorcik (2004) argues that those studies focused on the presence of FDI through horizontal spillovers and failed to look at the impacts of FDI through backward spillovers, which measure the relationship between domestic suppliers and their foreign buyers. Javorcik's argument that was confirmed by the empirical results of her study in Lithuanian firms found that there was no evidence about the impacts of FDI through horizontal spillovers when it could contribute positively through backward spillovers.

According to Blalock and Gertler (2008), the greater impacts of backward spillovers are due to foreign firms transferring technology to domestic suppliers with the motive to get

\footnotetext{
2 The five industries were selected because of their significant contribution to the economy of Indonesia as stated by the Ministry of Industry (2018)
} 
high-quality inputs at a lower price. On the other hand, the horizontal spillovers are difficult to achieve due to two reasons: first, the broad technology gap between the foreign and local firms can hinder the local firms from absorbing the advanced technology. Second, foreign firms tend to protect their technology in order to maintain their competitiveness. Their views were also supported by their empirical findings that showed that the insignificant effects were generated in horizontal spillovers, while they were positive and significant in backward spillovers.

The promising findings of the study conducted by Z. Liu (2008), who investigated the effects of FDI spillovers on the short and long term productivity of Chinese manufacturing firms, emphasized that the positive effects of FDI were likely to happen in the long run, while in the short run, they may be negative due to the costly running process. Supporting the studies of Javorcik (2004) and Blalock and Gertler (2008), Z. Liu also concludes that horizontal spillovers are not always significant in certain industries, while statistically backward spillovers are the most significant in influencing local firms.

Nevertheless, empirical studies in Indonesia provide contradictory results. One of the studies is conducted by Negara and Adam (2012), who applied the firm-level data from the Indonesia Annual Manufacturing Survey gathered between 1995 and 2005 and the I-O table from 2005. Their findings suggested that horizontal and forward spillovers positively contributed to local firms, while the contributions of backward spillovers were found to be negative. These results were also supported by Sari et al. (2016), who attempted to investigate the productivity gains of local firms by using the data of annual manufacturing survey 2003-2009 and the I-O tables in 2000 and 2005, and they concluded that the positive effects of FDI spillovers can happen in horizontal and forward spillovers, while the negative effects appear in backward spillovers.

The different results of Indonesian manufacturing industries suggest that each country has its characteristics. As regards the negative effects of backward spillover, Negara and Adam (2012) and Sari et al. (2016) express their concerns about some Indonesian industries' dependence on the use of imported raw or intermediate materials. This indicates that foreign firms are likely to use imported inputs because the domestic supplier cannot provide high-quality material at low cost. Thus, this situation can influence the performance of the domestic supplier, which can hinder their productivity.

In common, most of the studies including in Indonesia lack in explaining the characteristics of specified industrial sectors. To achieve those objectives, comprehensive results are needed, which can be found if the data in the analysis is disaggregated. One of the few studies that can be found is from Suyanto et al. (2012), who tried to investigate the impacts of FDI spillover on the garment and electronics industries. They found that the positive spillovers appeared in the garment industry, while the negative spillovers occurred in the electronic industry. Furthermore, Suyanto and Salim (2013) also found that the domestic suppliers could achieve positive spillovers in pharmaceuticals industry. $\mathrm{He}$ argues that the pharmaceuticals industry, which is technologyintensive, could absorb more technical efficiency from the presence of FDI.

Referring to literatures discussed above, this study will contribute to the existing literature with the analysis of disaggregated firm-levels data, which is still limited in Indonesia. This study is also the first attempts in capturing backward and forward spillover effects by using three times variations of I-O tables. With the use of more comprehensive and recent data, therefore, this study is expected to provide more relevant analysis related to FDI spillovers in manufacturing industries in Indonesia.

\section{RESEARCH METHOD}

\section{Methodology}

This study employed the unbalanced panel data analysis for the time period between 2000 and 2015. The empirical model for estimation, adapted from the works of Javorcik (2004) and Negara and Adam (2016), is as follows:

$$
\begin{aligned}
& \operatorname{lnP}_{i j t}=\beta_{0}+\beta_{1} \text { Horizontal }_{j t}+\beta_{2} \text { Backward }_{j t}+\beta_{3} \\
& \text { Forward }_{j t .}+\beta_{4} \text { ForeignShares }_{i j t}+\beta_{5} \text { Export }_{\mathrm{ijt}}+ \\
& \beta_{6} \text { Import }_{i j t}+\beta_{7} \text { MShares }_{i j t}+\varepsilon_{t}
\end{aligned}
$$


Here, $\ln P_{i j t}$ is the productivity level of the firm $i$ in the industry $j$ in the year $t$, measured by a firm's gross value added divided by the number of workers $\left(V A_{i i t} / L_{i i t}\right)$ and transferred to the $\ln$ value. Horizontal ${ }_{j t}$ is the horizontal spillovers of foreign presence in the same industry. Backward ${ }_{i t}$ is the vertical spillovers through backward spillovers in an industrial sector, while Forward $_{i t}$ is the vertical spillovers through forward spillovers. ForeignShares ${ }_{i j t}$ is the percentage of foreign ownership in a firm. Export $_{i j t}$ is the dummy variable, defined by 1 if a firm exports its product and 0 if otherwise. Similarly, Import $t_{i j t}$ is the dummy variable, defined by 1 if a firm uses imported materials and 0 if otherwise. MShares ijt $_{\text {is }}$ is the ratio of a firm's output to the total output in each industrial manufacturing sector.

The formulation of three channels of spillovers (horizontal, backward, and forward) were estimated as shown in Javorcik (2004). The estimation of horizontal spillovers can be written as follows:

$$
\text { Horizontal }_{j t}=\frac{\sum_{i \in j}(\text { ForeignShares } * Y)_{i t}}{\sum_{i \in j} Y_{i t}}
$$

Here, Horizontal ${ }_{i t}$ measures the presence of foreign firms at the sector $j$ at that time $t$, defined by the average of the percentage of foreign ownership (Foreign Share) and the output $(Y)$ of foreign firms in a sector, then weighted by each firm's output $(Y)$ in a sector. The subscript $i$ indicates the firm, while $j$ donates the industry, $t$ the time, and $i \in j$ the firms in a given industry.

Backward spillovers measure the potential relationship between local suppliers and foreign firms. The formulation of backward spillovers can be defined as follows:

$$
\text { Backward }_{j t}=\sum_{j \neq k} \propto_{j k} * \text { Horizontal }_{k t}
$$

Here, $\propto_{i k}$ is the backward linkage coefficient of the sector $j$ 's output supplied to sector $k$, calculated from the sums of the column of inverse matrix from I-O tables. In measuring the coefficient, the goods supplied to final consumption and inputs supplied within the sector are excluded (Javorcik, 2004). Table 1 lists the values of this coefficient in each sector based on 2-digits ISIC code.

On the other hand, forward spillovers capture the potential contacts between foreign firms and domestic buyers. It is determined by the weighted share of output in the supplying sector with foreign shares. The formulation of forward spillovers can be estimated as follows:

Table 1. Backward linkage coefficients

\begin{tabular}{ccccccccccc}
\hline Year & 10 & 11 & 14 & 13 & 15 & 21 & 20 & 29 & 30 & 26 \\
\hline 2000 & 1,0481 & 1,0737 & 1,2533 & 1,0865 & 1,0335 & 1,1120 & 0,9847 & 0,9657 & 0,9188 & 1,3116 \\
2001 & 1,0590 & 1,0665 & 1,2342 & 1,0837 & 1,0273 & 1,1065 & 1,0056 & 0,9476 & 0,9082 & 1,2913 \\
2003 & 1,0566 & 1,0650 & 1,2289 & 1,0807 & 1,0229 & 1,1022 & 1,0317 & 0,9424 & 0,9009 & 1,2798 \\
2004 & 1,0663 & 1,0678 & 1,2249 & 1,0764 & 1,0253 & 1,0996 & 1,0189 & 0,9395 & 0,9001 & 1,2728 \\
2005 & 1,1031 & 1,1740 & 1,1641 & 1,0661 & 1,0741 & 1,2012 & 1,0451 & 1,0023 & 0,9309 & 1,1635 \\
2006 & 1,1034 & 1,1658 & 1,1513 & 1,0621 & 1,0658 & 1,1931 & 1,0492 & 0,9940 & 0,9286 & 1,1475 \\
2007 & 1,0876 & 1,1544 & 1,1443 & 1,0590 & 1,0586 & 1,1855 & 1,0460 & 0,9907 & 0,9298 & 1,1402 \\
2008 & 1,0780 & 1,1389 & 1,1264 & 1,0535 & 1,0472 & 1,1762 & 1,0493 & 0,9819 & 0,9297 & 1,1223 \\
2009 & 1,0624 & 1,1294 & 1,1247 & 1,0528 & 1,0434 & 1,1703 & 1,0503 & 0,9819 & 0,9316 & 1,1202 \\
2010 & 1,0517 & 1,1264 & 1,0739 & 1,0563 & 1,0231 & 1,0359 & 1,0003 & 0,9090 & 0,9114 & 1,1961 \\
2011 & 1,0529 & 1,1243 & 1,0712 & 1,0542 & 1,0220 & 1,0332 & 0,9934 & 0,9119 & 0,9142 & 1,1879 \\
2012 & 1,0513 & 1,1226 & 1,0699 & 1,0528 & 1,0215 & 1,0318 & 0,9905 & 0,9134 & 0,9158 & 1,1839 \\
2013 & 1,0482 & 1,1193 & 1,0680 & 1,0507 & 1,0201 & 1,0301 & 0,9899 & 0,9147 & 0,9169 & 1,1794 \\
2014 & 1,0501 & 1,1120 & 1,0700 & 1,0481 & 1,0141 & 1,0249 & 0,9860 & 0,9178 & 0,9172 & 1,1815 \\
2015 & 1,0455 & 1,1066 & 1,0663 & 1,0457 & 1,0116 & 1,0244 & 0,9955 & 0,9181 & 0,9174 & 1,1746 \\
\hline
\end{tabular}

Source: Author's calculation from I-O Table 2000, 2005, 2010 (BPS)

Notes:

Based on 2-digits ISIC Code (2009)

10: Food; 11: Beverages; 14: Wearing apparel; 13: Textile; 15: Footwear \& leather; 21: Pharmacy; 20: Chemicals; 29: Vehicles; 30: Other transportation; 26: Electronics 
Forward $_{j t}=\sum_{j \neq m} \sigma_{j m} * \frac{\left[\sum_{i \in m} \text { ForeignShares } *\left(Y_{i t}-X_{i t}\right)\right]}{\sum_{i \in m}\left(Y_{i t}-X_{i t}\right)}$

Here, $\sigma_{i m}$ is the forward linkage coefficient that represents the inputs that are being purchased by the sector $j$ from the sector $m$. The values of this coefficient are calculated from the sums of the row of the inverse matrix from the I-O tables, which can be seen in Table 2. As pointed out by Javorcik (2004), the goods produced by foreign firms for exports $\left(X_{i t} X_{i t}\right)$ were excluded in this formula for the purpose of the study for measuring the intermediate goods in the domestic market.

\section{Data Sources}

The data used in this study was taken from the Annual Survey of Medium and Large Manufacturing Industries by Statistics Indonesia (BPS) for the period between 2000 and 2015. However, due to the unavailability of the firm ID in 2002, the observations of the year 2002 were excluded. This study also employed supplementary data from the I-O tables in capturing the backward and forward spillover effects. The I-O tables were taken from BPS for the periods of 2000, 2005, and 2010. The I-O tables for the year 2000 and 2005 provide 175 economic sectors, while the I-O table for the year 2010 captures 185 economic sectors. Before calculating the linkages, each sector in industrial sectors is analyzed and grouped into 2-digits ISIC code. In addition, the measurement of backward and forward linkages for the period 2001-2004, the I-O table for the year 2000 was used. Similarly, the I-O tables for the years 2005 and 2010 were used for the periods 2006-2009 and 2011-2015, respectively.

Furthermore, all monetary values in the primary and supplementary data are deflated using GDP deflator, calculated from nominal GDP and real GDP constant price in 2000 taken from BPS. The values of the Annual Survey of Medium and Large Manufacturing Industries were deflated using the GDP deflator in manufacturing sector, while the monetary values in I-O tables were deflated using the GDP deflator of nine sectors. The list of the sectors and the values of GDP deflator can be seen in Appendix 1.

The data in the Annual Survey of Medium and Large Manufacturing Industries were classified into sectors according to the Indonesia Standard Industrial Classification (ISIC) for the years 2000 (data 2000-2009) and 2009 (data

Table 2. Forward linkage coefficients

\begin{tabular}{ccccccccccc}
\hline Year & $\mathbf{1 0}$ & $\mathbf{1 1}$ & $\mathbf{1 4}$ & $\mathbf{1 3}$ & $\mathbf{1 5}$ & $\mathbf{2 1}$ & $\mathbf{2 0}$ & $\mathbf{2 9}$ & $\mathbf{3 0}$ & $\mathbf{2 6}$ \\
\hline 2000 & 3,8448 & 0,6593 & 0,5987 & 1,2566 & 0,6736 & 0,8312 & 6,0603 & 1,1297 & 1,2650 & 0,7097 \\
2001 & 3,5941 & 0,6812 & 0,6246 & 1,2426 & 0,6954 & 0,8402 & 5,6059 & 1,1017 & 1,2501 & 0,7265 \\
2003 & 3,5153 & 0,6961 & 0,6409 & 1,2553 & 0,7119 & 0,8530 & 5,5492 & 1,0737 & 1,2480 & 0,7402 \\
2004 & 3,4720 & 0,7096 & 0,6552 & 1,2621 & 0,7253 & 0,8639 & 5,4838 & 1,0748 & 1,2557 & 0,7528 \\
2005 & 2,6419 & 0,7074 & 0,7019 & 1,1882 & 0,7867 & 0,8650 & 5,3877 & 0,9021 & 1,1060 & 1,0616 \\
2006 & 2,5117 & 0,7294 & 0,7244 & 1,1807 & 0,8050 & 0,8755 & 5,0441 & 0,9010 & 1,0998 & 1,0579 \\
2007 & 2,4227 & 0,7457 & 0,7410 & 1,1755 & 0,8183 & 0,8849 & 4,7989 & 0,9022 & 1,0989 & 1,0560 \\
2008 & 2,2292 & 0,7725 & 0,7682 & 1,1529 & 0,8377 & 0,8942 & 4,2753 & 0,9061 & 1,0893 & 1,0444 \\
2009 & 2,1913 & 0,7806 & 0,7765 & 1,1515 & 0,8443 & 0,8992 & 4,1767 & 0,9041 & 1,0892 & 1,0443 \\
2010 & 2,1701 & 0,8091 & 0,7862 & 1,0610 & 0,7974 & 0,9532 & 4,0582 & 1,2364 & 0,9953 & 2,1579 \\
2011 & 2,1284 & 0,8186 & 0,7967 & 1,0627 & 0,8074 & 0,9584 & 3,9583 & 1,2279 & 0,9984 & 2,1196 \\
2012 & 2,1079 & 0,8234 & 0,8021 & 1,0635 & 0,8125 & 0,9610 & 3,9066 & 1,2236 & 1,0001 & 2,0999 \\
2013 & 2,0864 & 0,8285 & 0,8079 & 1,0649 & 0,8180 & 0,9642 & 3,8559 & 1,2193 & 1,0019 & 2,0805 \\
\hline
\end{tabular}

Source: Author's calculation from I-O Table 2000, 2005, 2010 (BPS)

Notes:

Based on 2-digits ISIC Code (2009)

10: Food; 11: Beverages; 14: Wearing apparel; 13: Textile; 15: Footwear \& leather; 21: Pharmacy; 20: Chemicals; 29: Vehicles; 30: Other transportation; 26: Electronics 
2010-2015). This study used the 2-digits code in the ISIC and adjusted the ISIC code for the year 2000 to the ISIC code for the year 2009 according to the guidebook of compatibility ISIC code, as published by BPS. Afterwards, each sector was grouped into five priority industries as stated by the Ministry of Industry (2018), namely, (1) food and beverages, (2) textiles, wearing apparel and footwear, (3) chemicals and pharmaceuticals, (4) electronics, and (5) automotive and transport equipment. The process of grouping the sectors into the five priorities industries followed the National Industrial Development Master Plan 2015-2035 (Ministry of Industry, 2015). The classification of each sector and the ISIC code in this study can be seen in Appendix 2.

In the model, the dependent variable was productivity, which is defined by the firm's gross value added divided by the number of workers. This measurement follows a calculation from Negara and Adam (2012). The first main independent variable, horizontal spillover, used the data pertaining to the percentage of foreign shares and value of firm outputs taken from the survey. To record the foreign presence, the foreign shares that were less than $10 \%$ were excluded, as they were not classified as foreign firms (OECD, 2008). The other two main variables, the backward and forward spillovers, were calculated from the coefficient of the backward and forward linkages in each sector, then multiplied by the horizontal values.

The control variables in this study were foreign shares, market shares, export, and import. While the data pertaining to the FDI share, which recorded foreign ownership, was already available in the survey, the market share was calculated by estimating the ratio of the firm's output to the total output in the given industrial sector. Moreover, the data of the export variable used the dummy variable from the firm, which, through the survey, answered whether they were exporting their products or not. However, the measurement of export in this study was different from the measurement in other studies in Indonesia which used the percentage of exports (Negara \& Adam, 2012; Sari et al., 2016). Due to the many missing values of the percentage of exports that could reduce the observations, this study used another measurement of exports in the survey for more observations. Another control variable in this study, import, was the dummy variable that represented the use of imported materials. If the firm had the value of imported material in the data, it was defined as 1 , while zero value was defined as 0 .

\section{RESULTS AND DISCUSSION}

\section{Empirical Results}

Appendix 3 shows the descriptive statistics of the main variables and control variables used in the estimations. The descriptive statistics compared all the selected industries and the five priorities industries by dividing the firms into foreign firms and local firms. The total number of observations in this study was 113,080 firms, which included 105,190 local firms and 7,890 foreign firms. Among other industries, the largest number of firms (both foreign and local) came from the food and beverages industry. This is not surprising, considering that this sector is the highest priority sector with the highest GDP contribution, reaching $34.99 \%$ in 2018 (Statistics Indonesia, 2019).

Appendix 3 shows that, in all the five priority industries and sector in the industry, the labor productivity of foreign firms was larger than local firms. The comparison between the sectors in the industry showed that foreign firms in the chemical and pharmaceutical industry had the highest labor productivity. For the FDI spillover in the three channels, the electronics industry had the maximal value in the horizontal and backward spillovers, while the chemical and pharmaceuticals industry had the maximal value in the forward spillovers.

In general, foreign firms' use of imported inputs was larger than that of local firms. The highest import in a sector occurred in the electronic industry, which showed the mean at 0.83 of the import variables. This might be characteristic of the electronics industry as it involves assembly lines, making them active importers of materials (Suyanto et al., 2012).

Most of the foreign firms also exported their products. The textile, wearing apparel, and footwear industry had the highest exports, with the mean at 0.74 of export variables in FDI firms. This 
high export was likely due to the increase in export opportunities and FDI in this industry during the late 1980s (Suyanto et al., 2012). Moreover, from 2007 to 2018, textile products were consistently the second largest contributors of exports value in the manufacturing products behind palm oil (Central Bank of Indonesia, 2019).

Table 3 illustrates the results pertaining to all the selected industries and each sector industry. As for all the selected industries, the findings showed a positive and significant correlation between horizontal FDI and the productivity of the firms from the same industry. For backward spillovers, the negative and significant result suggested that foreign firms failed to provide benefits to the productivity of local suppliers. Similarly, forward spillovers had a negative and significant impact in influencing the productivity of domestic buyers.

The control variables in this study included foreign shares, imports, exports, and market shares. There was a positive association between foreign shares and the labor productivity of the firms, meaning that an increase in the percentage of foreign ownership in a firm can positively influence productivity. As the measurement of the openness of the firms, the dummy variables of imports and exports, demonstrated a positive and significant correlation between all the selected industries. Moreover, another control variable in the model, market share, generated positive and significant findings in all estimation.

In the analysis of the disaggregate industries, almost all the results of the main variables in each industry were in line with the regression of all the selected industries. The horizontal spillovers showed the highest coefficient in the food and beverage industry, while the backward spillovers had the largest impact in the chemical and pharmaceutical industry. Surprisingly, the electronics industry had a different pattern among the other industries, which only generated significant results in the forward spillovers with a different sign.

The results of the control variables in each industry were mixed when compared to those of all the selected industries. The foreign share

Table 3. Estimation Results

\begin{tabular}{lcccccc}
\hline VARIABLES & 1 & 2 & 3 & 4 & 5 & 6 \\
\hline \multirow{2}{*}{ Horizontal } & & & & & & \\
& $0.0279^{* * *}$ & $0.0744^{* * *}$ & $0.0479^{* * *}$ & $0.0715^{* * *}$ & 0.0113 & $0.0587^{* *}$ \\
Backward & $(0.00303)$ & $(0.00909)$ & $(0.00703)$ & $(0.0144)$ & $(0.0157)$ & $(0.0279)$ \\
& $-0.0205^{* * *}$ & $-0.0577^{* * *}$ & $-0.0390^{* * *}$ & $-0.0663^{* * *}$ & 0.00252 & $-0.0576^{* *}$ \\
Forward & $(0.00279)$ & $(0.00843)$ & $(0.00536)$ & $(0.0137)$ & $(0.0107)$ & $(0.0246)$ \\
& $-0.000437^{*}$ & -0.000813 & $-0.0116^{* * *}$ & $-0.00163^{* * *}$ & $0.00270^{* *}$ & -0.00371 \\
Foreign Shares & $(0.000240)$ & $(0.000523)$ & $(0.00238)$ & $(0.000359)$ & $(0.00109)$ & $(0.00542)$ \\
& $0.00232^{* * *}$ & $0.00174^{* *}$ & $0.00184^{* * *}$ & $0.00403^{* *}$ & 0.000342 & 0.00214 \\
Import & $(0.000458)$ & $(0.000737)$ & $(0.000585)$ & $(0.00158)$ & $(0.00300)$ & $(0.00221)$ \\
& $0.0537^{* *}$ & 0.00873 & 0.0268 & $0.176^{* *}$ & -0.0236 & 0.137 \\
Export & $(0.0211)$ & $(0.0368)$ & $(0.0272)$ & $(0.0703)$ & $(0.195)$ & $(0.0895)$ \\
& $0.0948^{* * *}$ & $0.0973^{* * *}$ & $0.0959^{* * *}$ & $0.129^{* *}$ & -0.136 & 0.0590 \\
MShares & $(0.0172)$ & $(0.0284)$ & $(0.0223)$ & $(0.0603)$ & $(0.174)$ & $(0.101)$ \\
& $0.123^{* * *}$ & $0.246^{* * *}$ & $0.298^{* * *}$ & $0.136^{* * *}$ & $0.206^{* * *}$ & $0.0502^{* * *}$ \\
Constant & $(0.0197)$ & $(0.0453)$ & $(0.0602)$ & $(0.0329)$ & $(0.0569)$ & $(0.00933)$ \\
& $8.945^{* * *}$ & $8.779^{* * *}$ & $9.036^{* * *}$ & $9.881^{* * *}$ & $8.351^{* * *}$ & $9.683^{* * *}$ \\
& $(0.0148)$ & $(0.0202)$ & $(0.0291)$ & $(0.0571)$ & $(0.850)$ & $(0.0728)$ \\
Observations & 113,080 & 59,554 & 39,370 & 8,550 & 1,522 & 4,084 \\
R-squared & 0.735 & 0.743 & 0.656 & 0.759 & 0.707 & 0.777 \\
\hline
\end{tabular}

Source: Author's calculation (2019)

Notes:

1: All five priority industries; 2: Food and beverages; 3: Textiles, wearing apparel, and footwear; 4: Chemicals and pharmaceuticals; 5: Electronics; 6: Automotive and transport equipment

Robust standard errors in parentheses: ${ }^{* * *} \mathrm{p}<0.01,{ }^{* *} \mathrm{p}<0.05,{ }^{*} \mathrm{p}<0.1$ 
only gave significant results in the textile, wearing apparel, and footwear, the chemical and pharmaceutical, and the food and beverage industries. Among the other industries, the highest influence of foreign share appeared in the chemicals and pharmaceuticals industry. This is also supported by Appendix 3, which shows that the labor productivity is the highest in the FDI firms in the chemicals industry.

\section{Discussion}

In all the five priority industries, the positive and significant coefficient in horizontal spillovers showed that the presence of foreign firms fosters positive competition within local firms. A similar finding was reached by Negara and Adam (2012) and Sari et al. (2016), who examined this effect in manufacturing sectors in Indonesia. Furthermore, horizontal spillovers also generate the highest coefficient among two other spillovers in this study, which indicates that the presence of FDI is the most important channels in raising productivity of the firms. Surprisingly, this condition also appears in a study that investigated manufacturing industries in Indonesia, conducted by Sari et al. (2016).

As regards backward spillovers, the results of the negative and significant impact on productivity also confirmed the claims of Negara and Adam (2012) and Sari et al. (2016), who argue that, in all probability, foreign firms do not use materials from local suppliers and prefer to use imported inputs. This is also supported by the data from descriptive statistics in Appendix 3, which shows that the mean of import in foreign firms $(0.56)$ is greater than that of local firms (0.10).

On the other hand, the effect of foreign firms through forward spillovers on productivity can generate a negative and significant result. The result is not in accordance with the previous studies in Indonesia conducted by Sari et al. (2016) and Negara and Adam (2012), who found positive effects of the forward spillovers. One possible explanation for this might be that foreign firms do not provide qualified and low-cost inputs for their domestic buyers (Javorcik, 2004).

Furthermore, foreign shares have positive and significant impacts on the productivity of the firms. Due to advanced technology and high-quality human capital brought by foreign firms from their home countries, it is possible to make the production process more efficient, which will result in greater productivity (X. Liu et al., 2001; Moran et al., 2005). This result ties well with previous studies from Javorcik (2004), Sari et al. (2016), and Negara and Adam (2012).

The variable of market shares also demonstrated positive and significant effects. According to Negara and Adam (2012), the higher market share of the firms could influence the firms' productivity and maintain their competitiveness. Furthermore, the positive and significant effects of the variables of import and export indicate that the firms that are exporting and importing their products can benefit from international trade, which in turn can enhance their productivity. Therefore, the openness of the firms might be a significant channel in technology transfer (Keller, 2010; Sari et al., 2016).

The result of positive and significant horizontal spillovers in the food and beverage industry is consistent with the finding from Suyanto and Salim (2010). They believe that the presence of foreign firms in food and beverage makes the market more competitive, which forces local firms to increase their efficiency. In the textile, wearing apparel, and footwear industry, the findings are also in line with the study conducted by Suyanto et al. (2012). They analyzed the FDI spillovers on technical efficiency in the garment industry and argue that the presence of foreign firms has given local firms in this industry greater opportunity for increasing their efficiency.

A similar pattern of horizontal spillovers was obtained in the chemical and pharmaceutical as well as the automotive and transport equipment industries, which indicates that the presence of FDI helps local firms to compete positively by improving the productivity in these industries. However, the electronics industry showed insignificant results, which suggests that the presence of foreign firms does not give any benefits to the productivity of local firms from the same industry.

The possible explanations of positive and significant horizontal spillovers in the four industries (the food and beverage, textile, wearing apparel and footwear, chemical and 
pharmaceutical, and automotive and transport equipment industries) might be the moderate technological gap between local firms and foreign firms in these industries. According to Crespo and Fontoura (2007), the greater technological gap will ease the local firms to imitate foreign technology to achieve higher efficiency. Nevertheless, if the technological difference is too small, local firms cannot receive a significant technological transfer from foreign firms because there is no substantial room to increase productivity. This is also might be the reason of the insignificant results of horizontal spillovers in the electronic industry. As explained by Suyanto and Salim (2010), the characteristics of the electronic industry in Indonesia is homogenous. Therefore, the technological gap among firms is rather small. Another possibility why the FDI in horizontal spillovers might not occur is due to the technological protection from foreign firms, which hinders local firms to imitate their technology (Lenaerts \& Merlevede, 2011).

As regards backward spillovers, four industries (the food and beverage, textile, wearing apparel and footwear, chemical and pharmaceutical, and automotive and transport equipment industries) showed the same correlations, which were negative and significant. This condition demonstrates that foreign firms in these industries prefer not to use materials from local suppliers, tending to use imported inputs. The results were also confirmed by the data from the import variables in the four industries that showed a high mean value of imports in foreign firms when compared to that of local firms.

In the food and beverage industry, the high imported materials can be caused by the low supply of materials in the domestic market. According to Robiani (2008), there are some subindustries within in the food and beverage industry with a high percentage of imported materials, such as the milk, dairy, flour, and malt sub-industries. Other food and beverage sub-industries, such as the bakery and noodles sub-industries, also use the outputs from the other sub-industries.

Looking at the results of the negative backward spillovers from the textile, wearing apparel and footwear industries, a possible reason for that is the low quality of materials produced by the textile, wearing apparel and footwear industry in Indonesia. The low-quality of materials demonstrates two things, the abundance of low-skilled labor in Indonesia (Wie, 2005) and the use of old machinery in this industry (Ministry of Industry, 2017). Hence, most of the firms in this industry import their materials that are of better quality and available at competitive prices.

In the automotive and transport equipment industry, the problems become increasingly complex, because domestic suppliers are less competitive than foreign suppliers. According to Natsuda et al. (2015), the local activities in the automotive industry in Indonesia are not a major concern for the government. This can be seen from the absence of local content requirements in the assembly process and the lack of incentives for local firms to invest in or upgrade their production activities. The inability of local suppliers to compete make the assemblers, most of whom are foreign companies, prefer foreign suppliers in all the tiers.

The problem of inputs also appears in the chemical and pharmaceutical industry. According to the Ministry of Industry (2017), this is caused by a lack of supplied inputs and a lack of skilled workers. For instance, in the petrochemical industry, inputs such as naphtha and condensate are still imported due to the lack of industrial capability to locally produce these inputs. In addition, this industry also faces the problem of human resource, as many skilled workers working in local firms choose to move to foreign firms.

On the other hand, the electronics industry showed results that contrast with those of the other industries. Regardless of the insignificant effect, the positive backward spillovers indicate that local suppliers receive benefits from the presence of foreign companies. A possible reason for this might be the location of most electronics firms in Indonesia, which are located in special economic zones (Sedane Labor Information Agency, 2018). As argued by Howard et al. (2014), firms in the industrial cluster can receive benefits by reducing the transaction cost, operating more efficiently (as a consequence of the increase in competition), matching the workers with their jobs, and having access to more technology transfer. This way, the 
domestic suppliers in this area can receive more productivity gains from foreign buyers.

As for the forward spillovers, significant effects can be found in three industries, namely, the textile, wearing apparel and footwear, chemical and pharmaceutical, and electronics industries. While the first two industries showed negative results, the electronics industry showed positive effects. As Javorcik (2004) argues, the negative effects may be because foreign firms tend to sell their inputs to local firms at higher costs, which can affect the performance of local firms.

In contrast, the significant and positive effects of forward spillovers in the electronic industry indicate that this industry has a different pattern from the others. The reason is the same as that for the positive effects of backward spillovers: with the low transaction costs and other such advantages related to being located in special economic zones, domestic buyers can buy cheap products from foreign suppliers.

\section{CONCLUSION}

This study investigated the FDI spillover effects on labor productivity from five priority industries over the period between the years 2000 and 2015. This study tried to address the limitations of previous studies in Indonesia by using disaggregated firm-level data and more times variations of I-O tables in analyzing backward and forward spillovers. The empirical results were consistent with those of the previous studies in Indonesia conducted by Amani (2017), Negara and Adam (2012), and Sari et al (2016), which showed that FDI can contribute positively through horizontal spillovers, while the negative effect appears in backward spillovers. However, inconsistent results from previous studies in Indonesia appear in forward spillovers, which show negative effects.

As for the horizontal spillovers, the results showed that the transfer of knowledge is supported by the presence of FDI on the same industry level. On the other hand, the negative correlation in backward spillovers indicates that the foreign firms do not use inputs from domestic suppliers, which is also supported by the high mean of the imported inputs of the foreign firm variable. Furthermore, the negative effects of the forward spillovers show that foreign firms do not provide qualified and low-cost intermediate inputs for their domestic buyers. As regards the analysis of each industry, the results of most industries are still in line with the aggregate level, except for the electronics industry, for which the results in forward spillovers contrast with those of the rest.

Moreover, the difference in results in each spillover from this study indicates that FDI has not provided comprehensive benefits to local firms. Although the results of the horizontal spillovers show that policies promoting FDI have had a good influence on local firms, this is not enough for local firms to improve their productivity. Local firms, either as suppliers or as buyers for foreign firms, still find its difficulty to obtain benefits such as absorbing technology and knowledge from foreign firms.

In general, the problem faced by the five manufacturing industries is the use of mostly imported inputs. There are two causes behind this: the lack of domestically available materials and the low quality of local materials. Even though the decision to import materials is beneficial for firms as it gets them materials of better quality at lower prices, high dependence on imported inputs involves the risk of exchange rate fluctuations, which can affect the operation of the firms.

The examples of lack of supplied inputs occur in the food and beverage industry as well as the chemical and pharmaceuticals industry. To overcome the problem of importing inputs that are not yet domestically available, of course, requires large investments to boost domestic production. For this, the government could attract investment through various incentives and licensing facilities. The formulation of policies must also be strengthened by the implementation of regulations (the rule of law) and proper coordination between the government institutions to increase the confidence of domestic and foreign investors in the certainty of the business.

The problem of low-quality inputs appears in the textile, wearing apparel and footwear as well as the automotive and transport equipment industries. To improve the quality of inputs, policymakers can make policies that promote an increase in labor skills, strengthen innovation, 
and restructure machinery equipment. To provide high-quality labor, training is not only given on existing labor but also at an educational level. Moreover, the government can make continuous improvements to the vocational school curricula to facilitate a match in the skills of the graduates and the recent needs of the industry. Furthermore, to strengthen innovation, the government can provide facilities such as incentives, infrastructure, or assistance to support the development of research and development and the protection of intellectual property rights. As regards the machinery program, it has been held since 2007 . According to the Ministry of Industry (2017), this program has been successfully increasing the competitiveness of the industry. Therefore, this program should be continued with more intensive socialization so that the funds prepared can be appropriately absorbed.

Overall, policymakers must ensure that foreign firms could give benefits to local firms by making policy regarding technology transfer as a requirement for foreign investors to get incentives and other investment facilities. For example, foreign firms that build their research and development facilities or conduct joint research with universities can get tax allowance or tax holidays by the government.

Finally, this study suggests that there is scope for further research. The use of 2-digit ISIC industries is still too general to capture the characteristics of the industries, while there is a possibility that the analysis of more digit on ISIC can result in different findings. The author's means to capture the characteristics of each industry are also limited due to the lack of references in each of the five priorities industries in Indonesia. Therefore, it is hoped that this study can be further refined with more in-depth analyses for each industry. Furthermore, it would be interesting to learn more about the impact of industry agglomeration on the spillover effects or the productivity of the firms, since the data of the location of the firms, that, is whether it is inside or outside the industrial area, is already available in the survey since 2004.

\section{REFERENCES}

Aitken, B. J., \& Harrison, A. E. (1999). Do domestic firms benefit from direct foreign investment? Evidence from Venezuela. American Economic Review, 89(3), 605-618. https://doi.org/10.1257/aer.89.3.605

Amani, M. (2017). The impact of foreign direct investment on the manufacturing sector in Indonesia. National Graduate Institute for Policy Studies.

Athukorala, P. (2003). Foreign direct investment in crisis and recovery: Lessons from the 1997--1998 Asian crisis. Australian Economic History Review, 43(2), 197-213.

Barbosa, N., \& Eiriz, V. (2009). Linking corporate productivity to foreign direct investment: An empirical assessment. International Business Review, 18(1), 1-13. https://doi. org/10.1016/j.ibusrev.2008.10.003

Barrios, S., Görg, H., \& Strobl, E. (2011). Spillovers through backward linkages from multinationals: Measurement matters! European Economic Review, 55(6), 862-875. https://doi.org/10.1016/j. euroecorev.2010.10.002

Blalock, G., \& Gertler, P. J. (2008). Welfare gains from foreign direct investment through technology transfer to local suppliers. Journal of International Economics, 74(2), 402-421. https://doi.org/10.1016/j. jinteco.2007.05.011

Blalock, G., \& Simon, D. H. (2009). Do all firms benefit equally from downstream FDI the moderating effect of local suppliers capabilities on productivity gains. Journal of International Business Studies, 40(7), 1095-1112. https://doi.org/10.1057/ jibs.2009.21

Busse, M., \& Hefeker, C. (2007). Political risk, institutions and foreign direct investment. European Journal of Political Economy, 23(2), 397-415. https://doi.org/10.1016/j. ejpoleco.2006.02.003

Central Bank of Indonesia. (2018). Aliran investasi langsung di Indonesia menurut sektor ekonomi [Data file].

Central Bank of Indonesia. (2019). Nilai ekspor menurut komoditas [Data file]. https://www. 
bi.go.id/id/statistik/seki/terkini/eksternal/ Contents/Default.aspx

Chung, W. (2001). Identifying technology transfer in foreign direct investment: Influence of industry conditions and investing firm motives. Journal of International Business Studies, 32(2), 211-229. https://doi. org/10.1057/palgrave.jibs. 8490949

Crespo, N., \& Fontoura, M. P. (2007). Determinant factors of FDI spillovers - what do we really know? World Development, 35(3), 410-425. https://doi.org/10.1016/j. worlddev.2006.04.001

Djankov, S., \& Hoekman, B. (2000). Foreign Investment and Productivity Growth in Czech Enterprises. 49-64.

Driffield, N., \& Jindra, B. (2012). Challenging the roduction function approach to assess the developmental effects of FDI. European Journal of Development Research, 24(1), 32-37. https://doi.org/10.1057/ejdr.2011.50

Girma, S., Görg, H., \& Pisu, M. (2016). Exporting, linkages and productivity spillovers from foreign direct investment. Multinational Enterprises and Host Country Development, 41(1), 191-211. https://doi. org/10.1142/9789814749237_0010

Glass, A., \& Saggi, K. (2002). Multinational firms and technology transfer. Scandinavian Journal of Economics, 104(4), 495-513. https://doi.org/10.1111/1467-9442.00298

Gorg, H., \& Strobl, E. (2001). Multinational companies and productivity spillovers: A meta-analysis. The Economic Journal, 111(475), F723-F739. https://doi. org/10.1111/1468-0297.00669

Gorodnichenko, Y., Svejnar, J., \& Terrell, K. (2014). When does FDI have positive spillovers? Evidence from 17 transition market economies. Journal of Comparative Economics, 42(4), 954-969. https://doi. org/10.1016/j.jce.2014.08.003

Howard, E., Newman, C., Rand, J., \& Tarp, F. (2014). Productivity-enhancing manufacturing clusters: Evidence from Vietnam (WIDER Working Paper Series, Issue 071). World Institute for Development Economic Research (UNU-
WIDER). https://econpapers.repec.org/ RePEc:unu:wpaper:wp2014-071

Javorcik, B. S. (2004). Does foreign direct investment increase the productivity of domestic firms? in search of spillovers through backward linkages. The American Economic Review, 94(3), 605-627. https:// doi.org/10.1257/0002828041464605

Keller, W. (2010). International trade, foreign direct investment, and technology spillovers. In Handbook of the Economics of Innovation (Vol. 2, Issue 1, pp. 793-829). https://doi. org/10.1016/S0169-7218(10)02003-4

Konings, J. (2001). The effects of foreign direct investment on domestic firms. Economics of Transition and Institutional Change, 9(3), 619-633. https://doi.org/10.1111/14680351.00091

Lenaerts, K., \& Merlevede, B. (2011). Horizontal or Backward? FDI Spillovers and Industry Aggregation. In Department of Economics Working Paper, Ghent University.

Liu, X., Parker, D., Vaidya, K., \& Wei, Y. (2001). The impact of foreign direct investment on labour productivity in the Chinese electronics industry. International Business Review, 10(4), 421-439. https://doi.org/10.1016/ S0969-5931(01)00024-5

Liu, Z. (2008). Foreign direct investment and technology spillovers: Theory and evidence. Journal of Development Economics, 85(1-2), 176-193. https://doi.org/10.1016/j. jdeveco.2006.07.001

Mahmood, M. (2008). Labour productivity and employment in Australian manufacturing SMEs. International Entrepreneurship and Management Journal, 4(1), 51-62. https:// doi.org/10.1007/s11365-006-0025-9

Ministry of Industry. (2015). Rencana Induk Pembangunan Industri Nasional 2015-2035 [National Industry Development Master Plan 2015-2035].

Ministry of Industry. (2017). Rencana Kerja Direktorat Jenderal Industri Kimia, Tekstil, dan Aneka 2018 [Performance Plan of 
the Chemical, Textile, and Miscellenous Industries General Directorate].

Ministry of Industry. (2018). Making Indonesia 4.0. https://www.kemenperin.go.id/ download/18384

Moran, T., Graham, E. M., \& Blomstrom, M. (2005). Does foreign direct investment promote development? Peterson Institute for International Economics. https://econpapers. repec.org/RePEc:iie:ppress:3810

Natsuda, K., Otsuka, K., \& Thoburn, J. (2015). Dawn of industrialisation? The Indonesian automotive industry. Bulletin of Indonesian Economic Studies, 51(1), 47-68. https://doi. org/10.1080/00074918.2015.1016567

Negara, S. D., \& Adam, L. (2012). Foreign direct investment and firms' productivity level: Lesson learned from Indonesia. ASEAN Economic Bulletin, 29(2), 116-127. https:// doi.org/10.1353/ase.2012.0014

OECD. (2002). Foreign Direct Investment for development: Maximising benefits, minimising costs. OECD Publishing. https:// doi.org/10.1787/9789264199286-en

OECD. (2008). OECD benchmark definition of foreign direct investment. In $O E C D$ benchmark definition of foreign direct investment - forth edition. https://doi. org/10.1787/9789264064805-en

Robiani, B. (2008). The Performance of Indonesia's Food and Beverages Industry (Issue November).

Sari, D. W., Khalifah, N. A., \& Suyanto, S. (2016). The spillover effects of foreign direct investment on the firms' productivity performances. Journal of Productivity Analysis, 46(2), 199-233. https://doi. org/10.1007/s11123-016-0484-0

Sedane Labor Information Agency. (2018). Regional Risk Assessment: Electronics Industry, Indonesia (Issue December). http://electronicswatch.org/regional-riskassessment-electronics-industry-indonesiadecember-2018_2554862.pdf

Statistics Indonesia. (2019). PDB lapangan usaha [Data file]. https://www.bps.go.id/ site/resultTab
Suyanto, Bloch, H., \& Salim, R. A. (2012). Foreign direct investment spillovers and productivity growth in Indonesian garment and electronics manufacturing. Journal of Development Studies, 48(10), 1397-1411. https://doi.org/10.1080/00220388.2011.6 46992

Suyanto, \& Salim, R. (2013). Foreign direct investment spillovers and technical efficiency in the indonesian pharmaceutical sector: Firm level evidencey. Applied Economics, 45(3), 383-395. https://doi.org/10.1080/00 036846.2011 .605554

Suyanto, \& Salim, R. A. (2010). Sources of productivity gains from FDI in Indonesia: Is it efficiency improvement or technological progress? The Developing Economies, 48(4), 450-472. https://doi.org/10.1111/j.17461049.2010.00115.x

UNCTAD. (2017). World investment report 2017: Investment and the digital economy. https://unctad.org/en/PublicationsLibrary/ wir2017_en.pdf

Wie, T. K. (2005). The major channels of international technology transfer to Indonesia: An assessment. Journal of the Asia Pacific Economy, 10(2), 214-236. https:// doi.org/10.1080/13547860500071493

Xaypanya, P., Rangkakulnuwat, P., \& Paweenawat, S. W. (2015). The determinants of foreign direct investment in ASEAN: The first differencing panel data analysis. International Journal of Social Economics, 42(3), 239-250. https://doi.org/10.1108/ IJSE-10-2013-0238 


\section{APPENDICES}

Appendix 1. GDP Deflator of 9 (nine) sectors

\begin{tabular}{cccccccccc}
\hline Year & $\mathbf{1}$ & $\mathbf{2}$ & $\mathbf{3}$ & $\mathbf{4}$ & $\mathbf{5}$ & $\mathbf{6}$ & $\mathbf{7}$ & $\mathbf{8}$ & $\mathbf{9}$ \\
\hline 2000 & 1.0000 & 1.0000 & 1.0000 & 1.0000 & 1.0000 & 1.0000 & 1.0000 & 1.0000 & 1.0000 \\
2001 & 1.1243 & 1.0808 & 1.2008 & 1.1983 & 1.1712 & 1.1358 & 1.0984 & 1.0982 & 1.1366 \\
2002 & 1.2158 & 0.9470 & 1.2475 & 1.5598 & 1.3085 & 1.2833 & 1.2862 & 1.1743 & 1.1915 \\
2003 & 1.2721 & 0.9998 & 1.2879 & 1.8498 & 1.3985 & 1.3064 & 1.3915 & 1.2401 & 1.3702 \\
2004 & 1.3316 & 1.2820 & 1.3711 & 2.1776 & 1.5700 & 1.3593 & 1.4685 & 1.2864 & 1.5491 \\
2005 & 1.4344 & 1.8703 & 1.5468 & 2.3044 & 1.8833 & 1.4698 & 1.6528 & 1.4296 & 1.7177 \\
2006 & 1.6510 & 2.1813 & 1.7886 & 2.4777 & 2.2376 & 1.6048 & 1.8550 & 1.5824 & 1.9698 \\
2007 & 1.9960 & 2.5725 & 1.9860 & 2.5689 & 2.5039 & 1.7398 & 1.8567 & 1.6619 & 2.1914 \\
2008 & 2.5180 & 3.1382 & 2.4678 & 2.7269 & 3.2037 & 1.9006 & 1.8817 & 1.8518 & 2.4960 \\
2009 & 2.8971 & 3.2856 & 2.5917 & 2.7240 & 3.9581 & 2.0206 & 1.8405 & 1.9371 & 2.7947 \\
2010 & 3.2334 & 3.8456 & 2.6779 & 2.7212 & 4.4053 & 2.2036 & 1.9413 & 2.1109 & 3.0314 \\
2011 & 3.4645 & 4.6122 & 2.8498 & 2.9568 & 4.7357 & 2.3401 & 2.0360 & 2.2662 & 3.3741 \\
2012 & 3.6355 & 5.0350 & 2.9432 & 3.0990 & 4.9395 & 2.4280 & 2.0691 & 2.3654 & 3.6347 \\
2013 & 3.8592 & 5.2401 & 3.0429 & 3.3094 & 4.9818 & 2.5970 & 2.1801 & 2.5096 & 3.8757 \\
2014 & 4.0193 & 5.3188 & 3.0028 & 5.4740 & 5.3683 & 2.7069 & 3.6339 & 3.0137 & 3.7264 \\
2015 & 4.2738 & 4.6714 & 3.1254 & 6.0907 & 5.7020 & 2.8513 & 3.8814 & 3.1895 & 3.9558 \\
\hline
\end{tabular}

Source: Author's calculation

Notes: 1: Agriculture, livestock, forestry, fisheries; 2: Mining and excavation; 3: Manufacturing industry; 4: Electricity, gas and clean water; 5: Construction; 6: Trade, hotel and restaurant; 7: Transport and communication; 8: Financial, real estate \& company services; 9: Services

Appendix 2. ISIC Code for each five priorities industry

\begin{tabular}{|c|c|c|c|c|}
\hline No & Five Priorities Industries & Industrial Sector (ISIC) & $\begin{array}{l}\text { 2-digits ISIC } \\
\text { Code (2000) }\end{array}$ & $\begin{array}{l}\text { 2-digits ISIC } \\
\text { Code (2009) }\end{array}$ \\
\hline \multirow[t]{2}{*}{1.} & Food and Beverages & Food & 15 & 10 \\
\hline & & Beverages & 15 & 11 \\
\hline \multirow[t]{3}{*}{2.} & Textile and Apparel & Textile & 17 & 13 \\
\hline & & Wearing Apparel & 18 & 14 \\
\hline & & Leather \& Apparel & 19 & 15 \\
\hline \multirow[t]{2}{*}{3.} & Chemical & Chemical & 24 & 20 \\
\hline & & Pharmacy & 24 & 21 \\
\hline 4. & Electronic & $\begin{array}{l}\text { Computers, Electronic and Optical } \\
\text { Goods }\end{array}$ & 32 & 26 \\
\hline \multirow[t]{2}{*}{5.} & Automotive & Vehicles, Trailers and Semi-trailers & 34 & 29 \\
\hline & & Other Transport Equipment & 35 & 30 \\
\hline
\end{tabular}

The Spillover Effects ... (Martin Juda dan Toshihiro Kudo) $\mid 15$ 


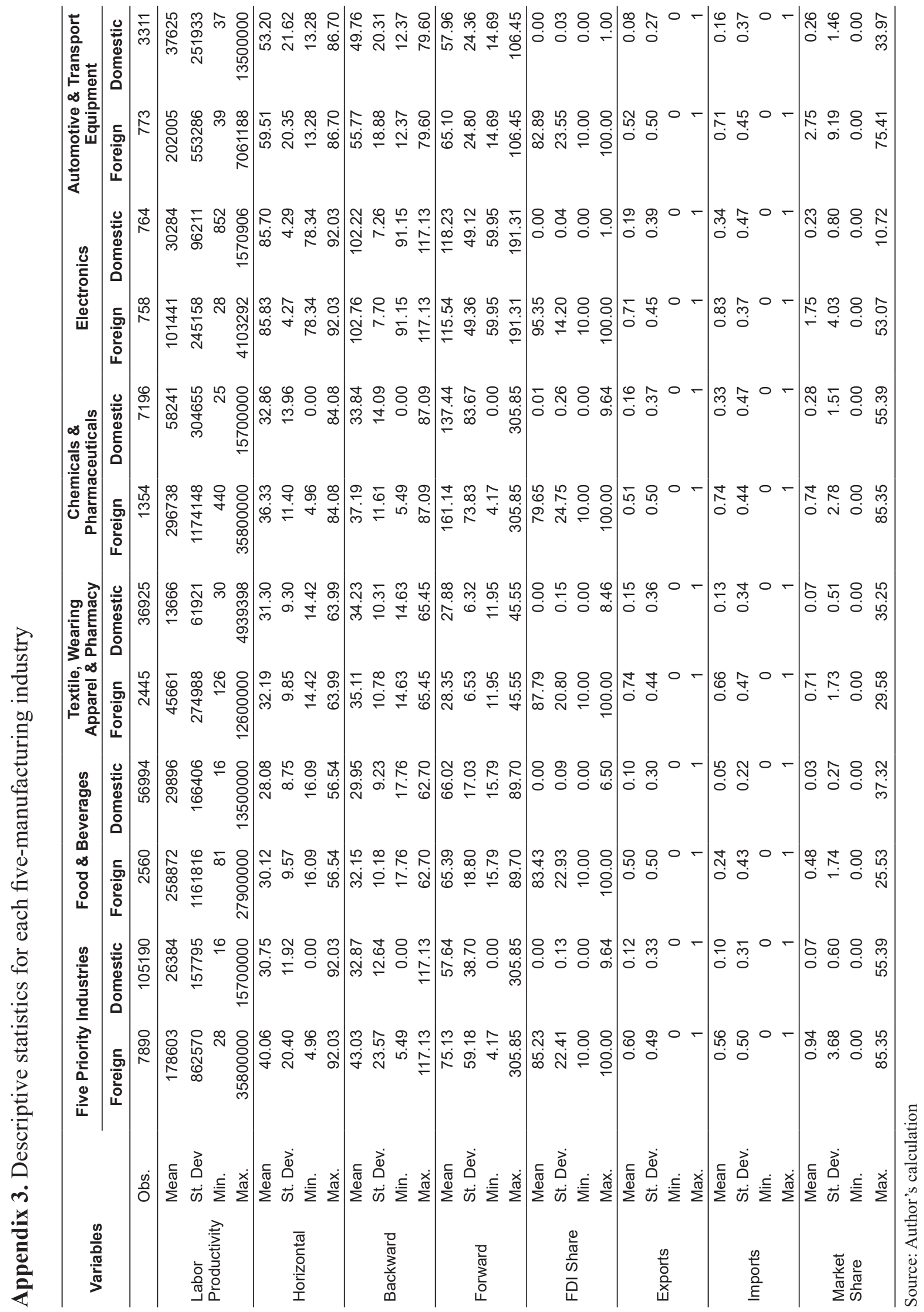

